\title{
Leading Trends in Innovative Development - Identification using Marketing Research
}

\author{
BOŻENA KACZMARSKA, WACŁAW GIERULSKI \\ Department of Management and Computer Modelling \\ Kielce University of Technology \\ Al. Tysiąclecia Państwa Polskiego 7, Kielce $25-314$ \\ POLAND
}

\begin{abstract}
Access to information has become extremely easy these days. Hence the common belief that we have established an information society in which knowledge is treated as the greatest wealth and which at the same time constitutes the basis for innovative development of enterprises, countries, regions. The paper presents identification of the leading areas of innovative technological development using marketing research. This allows the main objective to be fulfilled, which is to help choose the directions of research. . The source of data was the international exhibition of inventions held annually in Geneva, treated here as a case study. The research covered exhibitions held in 2017 and 2019, for which over 500 presented new solutions were classified each time. The results were confronted with a national event gathering inventors - the Polish National Student-Inventor Competition. Every year, approximately 100 solutions are submitted to the competition and then evaluated.
\end{abstract}

Key-Words: development, innovation, inventions, creators, ranking, areas of technology, marketing research

Received: May 21, 2021. Revised: November 28, 2021. Accepted: January 2, 2022. Published: January 3, 2022.

\section{Introduction}

The measure of prosperity is economic development. It results to a large extent from the development of technology, in close connection with the development of science. The development processes are continuous and their pace can be assessed to a large extent on the basis of agreed criteria. The amount of current and diverse information makes it difficult to reliably asses their current state of development. This depends to a large extent on the purpose of the assessment as well as the sensitivity and views of the person performing the analysis. What happened before lies in the domain of history, what will happen in the future is determined based on forecasts (Fig.1).

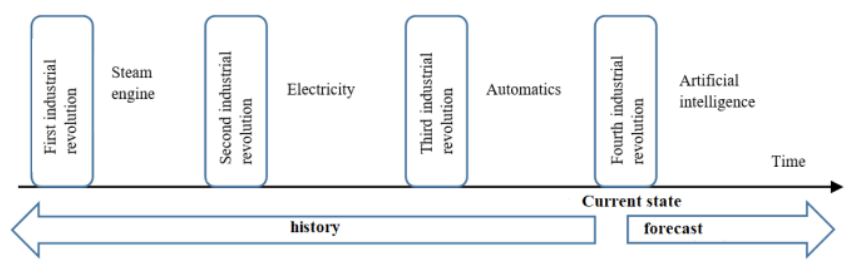

Fig.1: Assessment of development processes Source: Own elaboration

The easiest way to assess history is to use facts filtered out over time. In this assessment there are industrial revolutions that radically change the directions of development of science and technology. The turn of the $18^{\text {th }}$ and $19^{\text {th }}$ century was when the first industrial revolution took place, which started the period of mechanization by using steam engines in practice, which were extremely innovative at that time. The utilization of a steam engine for driving production machines dramatically increased productivity. As an example we can point out the spinning mills in England, where one steam engine was driving the machines in the production hall with the use of a large number of transmission belts. Transmission belts seen in old photographs were elements straight from the domain of modernity, but also the cause of many accidents. The steam engine contributed to the rapid development of transport. Steam engines and marine propulsion systems allowed to transport large quantities of goods in a much shorter time, which was another element of rapid development. This resulted in a sharp increase in demand for coal, which in turn led to the development of mining and the creation of large industrial districts.

The second industrial revolution dating back to the turn of the $19^{\text {th }}$ and $20^{\text {th }}$ century is related to the use of electricity. The dominant place was taken by the electric motor dedicated to individual machines, eliminating complex and dangerous transmission belt systems. It was the beginning of mass manufacture of products intended for large groups of consumers. Electricity, initially in the form of electrical engineering, developed into electronic 
engineering, which now also includes digital technologies, i.e. IT equipment and telecommunications. The electric motor, which used to be an innovative, expensive and thus selectively used type of drive, has become a component of many commonly used devices. Looking at a typical household, one can find many devices that use an electric motor, e.g.: a vacuum cleaner, a washing machine (drum drive and pump), a dishwasher (rotor drive and pump), a blender, a spit and the air circulation system in a gas-electric stove, a kitchen hood, a drill in a home workshop, a central heating furnace (fuel feeder, fan, water pump), the drive in garage and entrance gates. Additionally, small motors are used in analog clocks, in some programmable timers and in many children's toys previously equipped with spring drives and a windup mechanism.

The subsequent, third industrial revolution, associated with automation, took place in the 1970s. Various types of automatic systems for controlling temperature, pressure, flow rate, speed of movement, etc. were developed and became widespread. Industrial companies started to use numerically controlled machine tools and robots performing properly programmed sequences of activities. Autopilots became a standard in airplanes, just like cruise control in cars, and systems adjusting the amount of light falling on the photosensitive element in a camera. Automatic washing machines and dishwashers, or automatic vacuum cleaners, became common in households.

Advanced automation systems sometimes also take into account the possibility of making independent decisions. This is related to the beginning of the fourth industrial revolution at the turn of the $20^{\text {th }}$ and $21^{\text {st }}$ century, i.e. a period of extremely intensive development of computer science in general. An example of solutions illustrating the fourth revolution are advanced automation systems with the option of artificial intelligence assistance and Internet access. At the informational level, the elements of the manufacturing processes are interconnected, allowing for greater efficiency [16]. In everyday life, the fourth revolution is present in the form of self-driving, autonomous cars, or intelligent fridges automatically ordering food supplies.

The considerations on the current state of development of science and technology are connected with predicting the future. This is performed under conditions of uncertainty and, as history shows, has a moderate efficacy $[1,9]$. One of the methods of obtaining information on this subject is to observe novelties on the market, new products presented at various fairs, exhibitions, competitions and trends concerning patent applications.

\section{The Objective and the Methodology of the Research}

The objective of the conducted research is to identify the leading areas of innovative technological development. This provides assistance in the selection of research directions.

The thematic scope and the assumed objective defined the research approach used in the paper. In the conceptual/theoretical layer, based on the analysis of the literature, comparative analyses and desk-research, conclusions of a deductive nature have been made [6]. The observational/empirical layer, on the other hand, required conclusions of inductive/deductive nature with the use of various research methods, including the commonly known methods of structured data analysis performed on data obtained through the analysis of application questionnaires for solutions participating in the Polish National Student-Inventor Competition and the analysis of case studies - The International Exhibition of Inventions of Geneva. In selected cases, the method of analysis and logical construction was also used, supported by preparation of static and dynamic models.

The source of data for this research is The International Exhibition of Inventions of Geneva (Geneva Inventions), held annually in Geneva, treated here as a case study. The research covers exhibitions in 2017 and 2019, for which each time over 500 presented new solutions were classified. The results were confronted with a national event gathering inventors - the Polish National StudentInventor Competition. Every year, more than 100 solutions are submitted to the competition and then evaluated. $[3,4,7,8,15]$

The International Exhibition of Inventions of Geneva is one of the largest and most prestigious exhibition of inventions in Europe, bringing together creators of new solutions from around the world (Fig. 2). It is organized annually under the patronage of the International Federation of Inventors Associations (IFIA), the World Intellectual Property Organization (WIPO), the Swiss Federal Government, and the State the City of Geneva. 


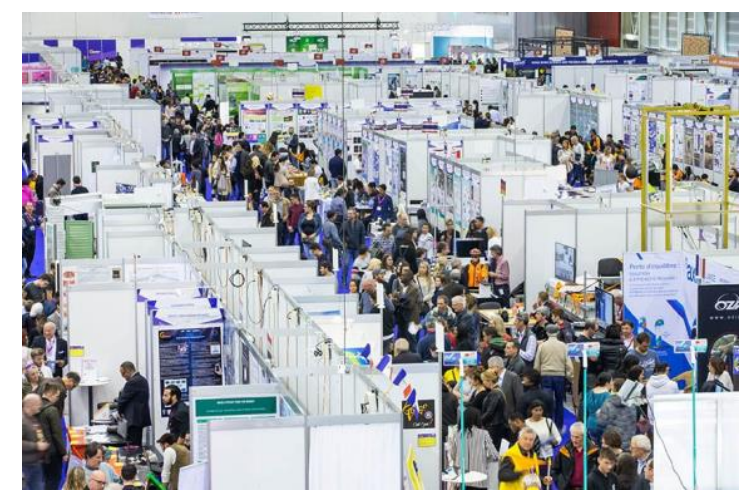

Fig.2: The International Exhibition of Inventions Geneva, Palexpo

Source: [14]

Among the exhibitors there are independent creators, representatives of universities, research institutes, government agencies and industrial companies from all over the world. The exhibition is a forum for exchanging ideas and experiences between inventors, scientists, entrepreneurs and investors. According to the organizers, more than $45 \%$ of the solutions presented at the exhibition in 2017 were licensed and the value of concluded contracts exceeded 50 million USD. These huge funds invested by the business world reinforce the belief that the exhibition is an element of creating the future, and the information collected constitute a valuable material in the process of searching for leading areas of technology development. [14]

The solutions presented during the exhibition are assessed by an international jury of about 70 experts. The presented solutions are classified into 21 categories $(\mathrm{A}-\mathrm{V})$, within which medals and distinctions are awarded (Table 1).

Table 1. Assessment categories - Geneva Inventions

\begin{tabular}{|l|l|}
\hline A & $\begin{array}{l}\text { Mechanics, Engines, Machinery, Tools, } \\
\text { Industrial Processes, Metallurgy }\end{array}$ \\
\hline B & Clocks and watches, Jewellery, Machinery, Tools \\
\hline C & $\begin{array}{l}\text { Computer sciences, Software, Electronics, } \\
\text { Electricity, Methods of communication }\end{array}$ \\
\hline D & $\begin{array}{l}\text { Building, Architecture, Civil Engineering, } \\
\text { Construction, Materials, Woodwork }\end{array}$ \\
\hline E & Sanitation, Ventilation, Heating \\
\hline F & Security, Rescue, Alarm \\
\hline G & Ironmongery, Do-It-Yourself \\
\hline H & Furnishing, Interior architecture \\
\hline I & Domestic Science, Restaurant equipment \\
\hline J & Commercial, Industrial and office equipment \\
\hline K & Agriculture, Horticulture, Gardening \\
\hline L & Clothing, Textiles, Machines and accessories \\
\hline
\end{tabular}

\begin{tabular}{|l|l|}
\hline M & $\begin{array}{l}\text { Medicine, Surgery, Hygiene, Orthopaedics, } \\
\text { Material for the handicapped }\end{array}$ \\
\hline N & Optics, Photography, Cinematography \\
\hline O & $\begin{array}{l}\text { Teaching methods and materials, Musical } \\
\text { instruments, Art materials }\end{array}$ \\
\hline P & $\begin{array}{l}\text { Transport, Motor vehicles, Ships, Aviation, } \\
\text { Accessories }\end{array}$ \\
\hline Q & $\begin{array}{l}\text { Foodstuffs, Drinks, Cosmetics, Paramedical, } \\
\text { Health, Hygiene }\end{array}$ \\
\hline R & Sport, Leisure \\
\hline S & Practical novelties, Presents \\
\hline T & Publicity, Printing, Packaging \\
\hline U & Games, Toys \\
\hline V & Protection of the environment, Energy \\
\hline
\end{tabular}
Source: [8]

\section{The Polish National Student-Inventor} Competition is a cyclical undertaking that has been organized by the Kielce University of Technology since 2010. The competition promotes the creative potential of Polish students-inventors at home and abroad, stirs the academic community into research and development activities, provides support in the process of commercialization of the results of research and development works protected by exclusive rights or submitted for protection, and increases the interest of students in finding innovative solutions for their own business. It is addressed to students and doctoral students who have applied for protection or obtained protection for their solutions. The vast majority of solutions taking part in the competition are the result of scientific and research activities of teams where at least one person has a status of a student or a doctoral student $[4,15]$. In total, in ten editions of the competition (2011-2020), 935 solutions were submitted, which are the result of research and development work of over two thousand creators. The main prize winners take part in subsequent editions of The International Exhibition of Inventions of Geneva. [4]

\section{Data analysis and assessment}

The set of solution categories presented at The International Exhibition of Inventions of Geneva is imposed by the organizers of the exhibition, and the classification is largely dependent on the subjective assessment of experts. However, by agreeing with the rules of classification so defined, it is possible to make an attempt to predict the directions of technical development. For this purpose, four groups were singled out depending on the number of solutions assigned to subsequent categories and the number of solutions presented by individual 
exhibitors (Fig.3). The countries of origin of the teams presenting the solutions were used to identify the exhibitors, which is consistent with the interpretation of the evaluation committee.

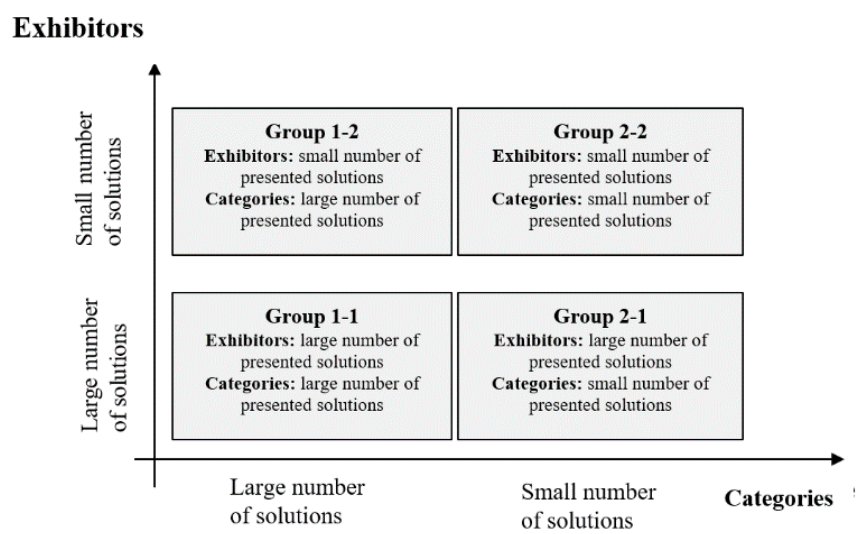

Fig.3: Exhibition of inventiveness - classification of solutions

\section{Source: Own elaboration}

\section{Group 1-1}

This group includes exhibitors (countries) with a large number of proposals for innovative solutions. In addition, these solutions belong to the categories with a large number of solutions.

Group 1-2

This group is made up of exhibitors (countries) with a small number of proposals, often single solutions. In addition, these solutions belong to the categories with a large number of solutions.

Group 2-1

This group includes exhibitors (countries) with a large number of innovative solution proposals mostly assigned to other more popular categories. However, this group includes not very popular, sometimes single solutions.

Group 2-2

This group consists of exhibitors (countries) with a small number of solutions, assigned to not very popular categories.

According to the presented concept of division, the leading areas of innovative development are defined by solutions assigned to group 1-1. It was assumed that this group consists of $80 \%$ of solutions assigned to the most active exhibitors and the most numerous categories. Due to the application of the two-parameter classification model, this group includes $90 \%$ of the initial items from the exhibitors' ranking list and the category ranking list. The remaining groups of the classification model include only $20 \%$ of the solutions that will not be taken into account when defining the leading areas of innovative development.
The applied $80 \%-20 \%$ division results from considerations supported by the method of analysis and logical construction with reference to the Pareto principle used in the description of natural phenomena of unequal division. The indicated limits of $80 \%, 20 \%, 90 \%$ should be treated as estimates, especially in cases with a discrete scale of assignment.

\section{Geneva Inventions - Case Study Geneva Inventions - 2017}

In 2017 the $45^{\text {th }}$ International Exhibition of Inventions of Geneva took place. On an area of 8500 $\mathrm{m}^{2}$, over 700 exhibitors from 38 countries presented new solutions, i.e. inventions, research results and new innovative products. The competition committee evaluated 569 solutions according to the adopted categories. [7] In other cases, the exhibitors did not agree to perform the evaluation.

Table 2 presents the ranking of exhibitors classified to group 1-1, indicating the number of all presented solutions (also belonging to group 2-1), and the percentage share. This group included 16 exhibitors from the top of the ranking list representing $91.2 \%$ of the total number of solutions. The ranking of exhibitors classified to group 1-1 is presented in graphic form in Fig.4, where additionally the number of solutions belonging only to group 1-1 is indicated.

Table 2. Geneva 2017 - exhibitors

\begin{tabular}{|c|c|c|c|c|}
\hline 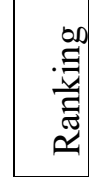 & Exhibitor & 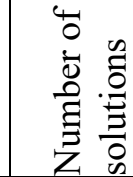 & 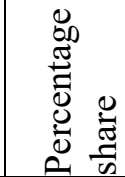 & 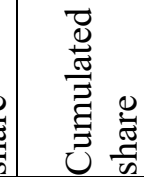 \\
\hline 16 & Italy & 12 & $2.1 \%$ & $91.2 \%$ \\
\hline 15 & Saudi Arabia & 12 & $2.1 \%$ & $89.1 \%$ \\
\hline 14 & Croatia & 13 & $2.3 \%$ & $87.0 \%$ \\
\hline 13 & Switzerland & 16 & $2.8 \%$ & $84.7 \%$ \\
\hline 12 & Poland & 17 & $3.0 \%$ & $81.9 \%$ \\
\hline 11 & Egypt & 17 & $3.0 \%$ & $78.9 \%$ \\
\hline 10 & Malaysia & 18 & $3.2 \%$ & $75.9 \%$ \\
\hline 9 & France & 20 & $3.5 \%$ & $72.8 \%$ \\
\hline 8 & South Korea & 24 & $4.2 \%$ & $69.2 \%$ \\
\hline 7 & Russia & 25 & $4.4 \%$ & $65.0 \%$ \\
\hline 6 & Iran & 31 & $5.4 \%$ & $60.6 \%$ \\
\hline 5 & Chinese Taipei & 42 & $7.4 \%$ & $55.2 \%$ \\
\hline 4 & Romania & 47 & $8.3 \%$ & $47.8 \%$ \\
\hline 3 & Hong Kong & 50 & $8.8 \%$ & $39.5 \%$ \\
\hline 2 & China & 83 & $14.6 \%$ & $30.8 \%$ \\
\hline 1 & Thailand & 92 & $16.2 \%$ & $16.2 \%$ \\
\hline
\end{tabular}

Source: Own elaboration based on [7] 


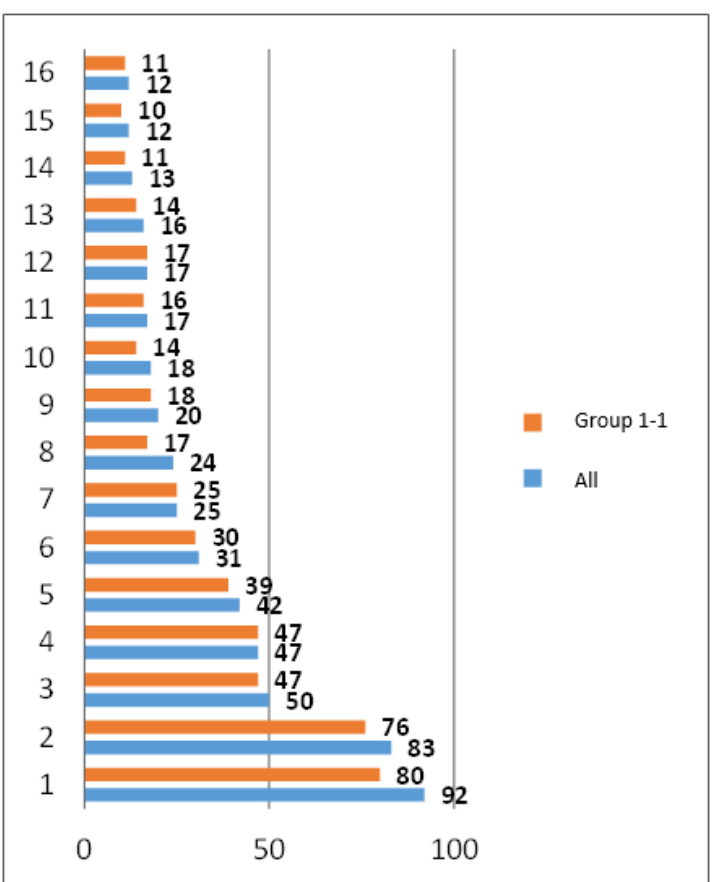

Fig.4: Geneva 2017 - exhibitors (Table 2)

Source: Own elaboration

Table 3 presents the ranking of categories classified to group 1-1 depending on the number of all presented solutions (also belonging to group 12). Subsequent rows of the table show percentage shares and cumulative percentage shares. Group 1-1 includes 12 categories from the top of the ranking list, which covers $90.9 \%$ of the total number of presented solutions. A ranking of categories in graphic form is also presented in Fig.5, where additionally the number of solutions belonging only to group 1-1 is indicated.

Table 3. Geneva 2017 - Categories

\begin{tabular}{|c|c|c|c|c|c|c|c|c|c|c|c|c|}
\hline Categories & $\mathrm{V}$ & $\mathrm{Q}$ & M & A & C & $\mathrm{P}$ & D & F & $\mathrm{K}$ & $\mathrm{R}$ & E & L \\
\hline $\begin{array}{l}\text { Number of } \\
\text { solutions }\end{array}$ & 80 & 71 & 70 & 64 & 59 & 46 & 41 & 24 & 18 & 18 & 13 & 13 \\
\hline Percentage & $\stackrel{\circ}{\stackrel{\Xi}{\dot{I}}}$ & ì & 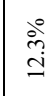 & $\stackrel{\text { \ે }}{=}$ & के & $\frac{\circ}{\infty}$ & ڤે̀ & 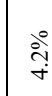 & ڤે̀ & ふें & iें & $\stackrel{\text { ले }}{\mathrm{i}}$ \\
\hline $\begin{array}{l}\text { Cumulated } \\
\text { share }\end{array}$ & $\stackrel{\circ}{\dot{\Xi}}$ & ถें & ळ. & $\stackrel{\circ}{\stackrel{\circ}{\circ}}$ & हैं & 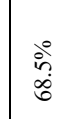 & हें & 今े & $\frac{\stackrel{0}{\circ}}{\infty}$ & कें & $\begin{array}{c}0 \\
\dot{0} \\
\infty \\
\infty\end{array}$ & தัे \\
\hline Ranking & 1 & 2 & 3 & 4 & 5 & 6 & 7 & 8 & 9 & 10 & 11 & 12 \\
\hline
\end{tabular}

Source: Own elaboration based on [7]

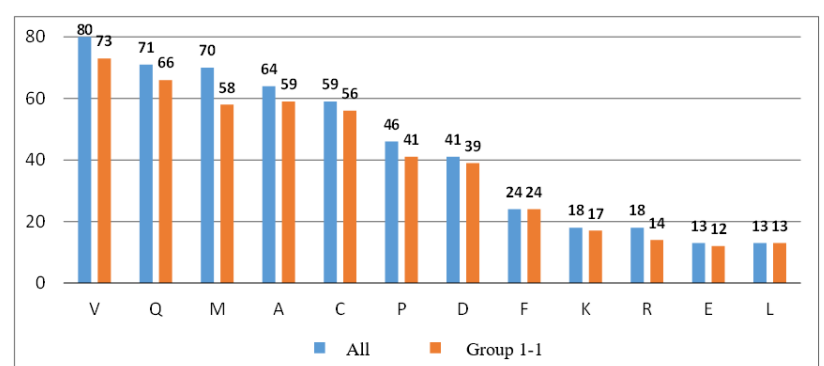

Fig.5: Geneva 2017 - number of solutions in each category

Source: Own elaboration

With regard to the two-parameter classification for the 2017 data, group 1-1 includes 16 exhibitors with solutions belonging to 12 categories. Out of the total number of 569 presented solutions, 472 solutions were assigned to this group, which constitutes $83.0 \%$.

\section{Geneva Inventions - 2019}

In April 2019 the $47^{\text {th }}$ International Exhibition of Inventions of Geneva took place. Over 800 exhibitors from 44 countries presented their solutions, i.e. inventions, research results and new innovative products. The competition committee evaluated 681 solutions according to the adopted categories. [8]

Table 4 presents a ranking of exhibitors classified to group 1-1, indicating the number of all presented solutions (also belonging to group 2-1), and the percentage share. This group included 14 exhibitors from the top of the ranking list representing $89.7 \%$ of the total number of solutions. The ranking of exhibitors classified to group 1-1 is presented in graphic form in Fig.6, where additionally the number of solutions belonging only to group 1-1 is indicated.

Table 4. Geneva 2019 - Exhibitors

\begin{tabular}{|c|c|c|c|c|}
\hline 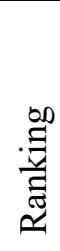 & Exhibitor & 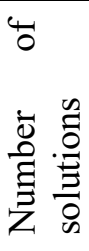 & 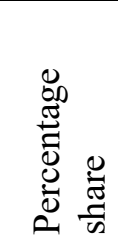 & 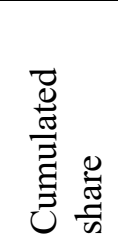 \\
\hline 14 & Croatia & 11 & $1.6 \%$ & $89.7 \%$ \\
\hline 13 & France & 12 & $1.8 \%$ & $88.1 \%$ \\
\hline 12 & Poland & 13 & $1.9 \%$ & $86.3 \%$ \\
\hline 11 & Switzerland & 15 & $2.2 \%$ & $84.4 \%$ \\
\hline 10 & Saudi Arabia & 16 & $2.3 \%$ & $82.2 \%$ \\
\hline 9 & Iran & 22 & $3.2 \%$ & $79.9 \%$ \\
\hline 8 & Egypt & 24 & $3.5 \%$ & $76.7 \%$ \\
\hline 7 & South Korea & 28 & $4.1 \%$ & $73.1 \%$ \\
\hline 6 & Romania & 34 & $5.0 \%$ & $69.0 \%$ \\
\hline 5 & Russia & 37 & $5.4 \%$ & $64.0 \%$ \\
\hline 4 & Chinese Taipei & 44 & $6.5 \%$ & $58.6 \%$ \\
\hline
\end{tabular}




\begin{tabular}{|l|l|l|l|l|}
\hline 3 & Thailand & 101 & $14.8 \%$ & $52.1 \%$ \\
\hline 2 & Hong Kong & 119 & $17.5 \%$ & $37.3 \%$ \\
\hline 1 & China & 135 & $19.8 \%$ & $19.8 \%$ \\
\hline
\end{tabular}

Source: Own elaboration based on [8]

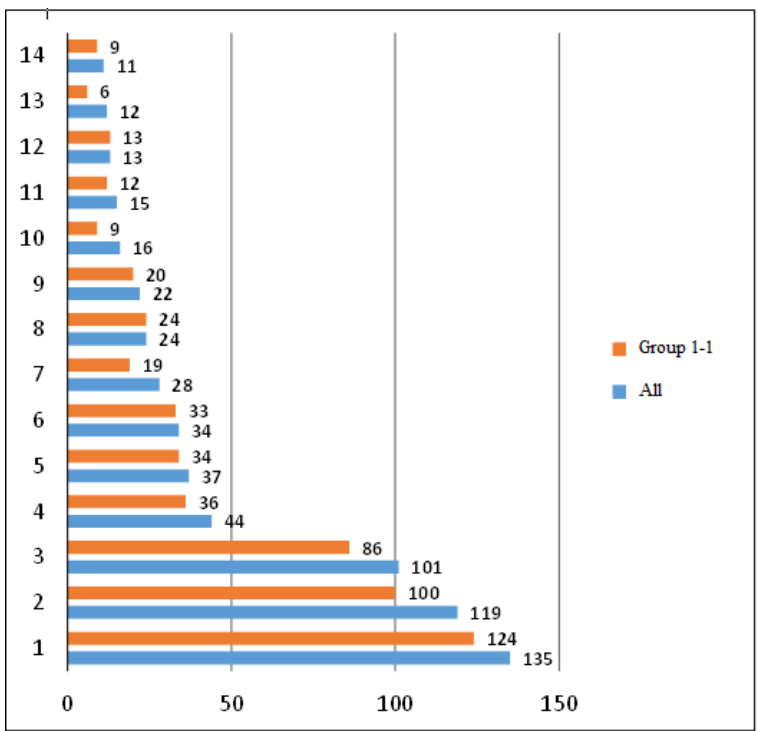

Fig.6: Geneva 2019 - exhibitors (Table 4)

Source: Own elaboration

Table 5 presents a ranking of categories classified to group 1-1 depending on the number of all presented solutions (also belonging to group 12). Subsequent rows of the table show percentage shares and cumulative percentage shares. Group 1-1 includes 11 categories from the top of the ranking list, which covers $87.81 \%$ of the total number of presented solutions. A ranking of categories in graphic form is also presented in Fig.7, where additionally the number of solutions belonging only to group 1-1 is indicated.

Table 5. Geneva 2019 - Categories

\begin{tabular}{|c|c|c|c|c|c|c|c|c|c|c|c|}
\hline Categories & $\mathrm{C}$ & M & $\mathrm{V}$ & Q & A & F & $\mathrm{D}$ & $\mathrm{P}$ & K & $\mathrm{L}$ & 0 \\
\hline Number of solutions & 114 & 86 & 84 & 74 & 63 & 41 & 40 & 32 & 29 & 19 & 16 \\
\hline Percentage share & 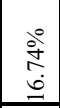 & $\begin{array}{l}\stackrel{0}{0} \\
\hat{\sigma} \\
\text { in }\end{array}$ & 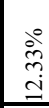 & 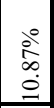 & $\begin{array}{l}\text { iें } \\
\text { aे }\end{array}$ & 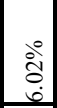 & $\begin{array}{l}0 \\
0 \\
0 \\
0\end{array}$ & $\stackrel{\stackrel{\circ}{+}}{+}$ & $\begin{array}{l}\stackrel{0}{0} \\
\text { ì }\end{array}$ & $\begin{array}{l}\stackrel{\circ}{\circ} \\
\text { ì }\end{array}$ & iे \\
\hline Cumulated share & 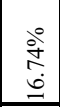 & $\begin{array}{l}\text { aे } \\
\text { iे. } \\
\text { aे } \\
\end{array}$ & $\begin{array}{l}\stackrel{0}{?} \\
\stackrel{\vec{\sigma}}{.}\end{array}$ & \begin{tabular}{l}
0 \\
\multirow{2}{n}{} \\
$i$ \\
$i$
\end{tabular} & $\begin{array}{l}\text { ○ें } \\
\infty \\
\dot{0} \\
\end{array}$ & 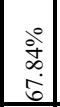 & $\mid \begin{array}{c}0 \\
\hat{N} \\
\stackrel{2}{2}\end{array}$ & $\begin{array}{l}\stackrel{\circ}{\overrightarrow{7}} \\
\stackrel{\infty}{c}\end{array}$ & $\begin{array}{l}\circ \\
\hat{6} \\
\text { d. } \\
\end{array}$ & $\begin{array}{c}0 \\
\dot{b} \\
\dot{b} \\
\infty \\
\infty\end{array}$ & $\begin{array}{l}\stackrel{\circ}{0} \\
\infty \\
\dot{\infty} \\
\end{array}$ \\
\hline Ranking & 1 & 2 & 3 & 4 & 5 & 6 & 7 & 8 & 9 & 10 & 11 \\
\hline
\end{tabular}

Source: Own elaboration based on [8]

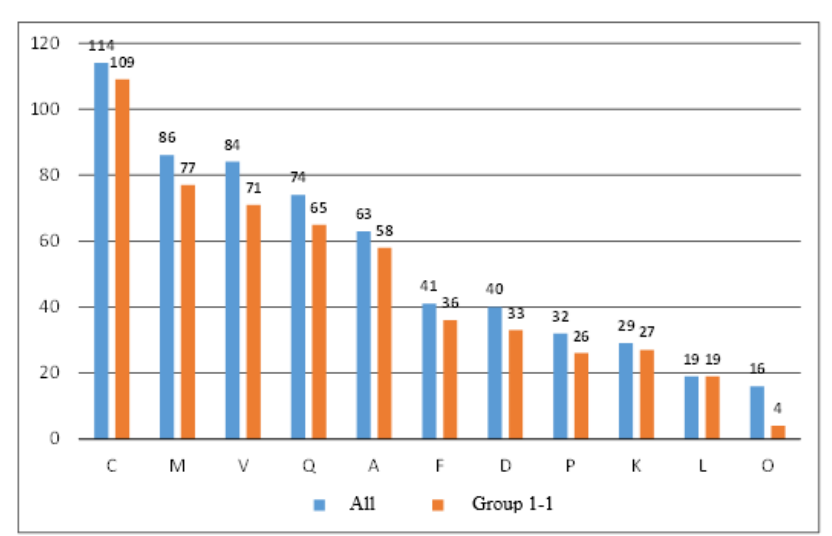

Fig.7: Geneva 2019 - number of solutions in each category

Source: Own elaboration

With regard to the two-parameter classification for the 2019 data, group 1-1 includes 16 exhibitors with solutions belonging to 12 categories. Out of the total number of 681 presented solutions, 525 solutions were assigned to this group, which constitutes $77.1 \%$.

\section{Leading trends in innovative development}

As a result of the analysis of data for 2017 and 2019 , two sets of categories of evaluated solutions assigned to group 1-1 were obtained. Assuming the common part of these sets as the implementation of the objective of the paper, 10 leading areas of innovative development can be identified (Table 6).

Table 6. Leading trends

\begin{tabular}{|l|l|}
\hline A & $\begin{array}{l}\text { Mechanics, Engines, Machinery, Tools, } \\
\text { Industrial processes, Metalurgy }\end{array}$ \\
\hline C & $\begin{array}{l}\text { Computer sciences, Software, Electronics, } \\
\text { Electricity, Methods of communication }\end{array}$ \\
\hline D & $\begin{array}{l}\text { Building, Architecture, Civil Engineering, } \\
\text { Construction, Materials, Woodwork }\end{array}$ \\
\hline F & Security, Rescue, Alarm \\
\hline K & Agriculture, Horticulture, Gardening \\
\hline L & Clothing, Textiles, Machines and accessories \\
\hline M & $\begin{array}{l}\text { Medicine, Surgery, Hygiene, Orthopaedics, } \\
\text { Material for the handicapped }\end{array}$ \\
\hline P & $\begin{array}{l}\text { Transport, Motor vehicles, Ships, Aviation, } \\
\text { Accessories }\end{array}$ \\
\hline Q & $\begin{array}{l}\text { Foodstuffs, Drinks, Cosmetics, Paramedical, } \\
\text { Health, Hygiene }\end{array}$ \\
\hline V & Protection of the environment, Energy \\
\hline Source Orn elaboration
\end{tabular}

\section{Source: Own elaboration}

The indicated leading trends in innovative development are based on the categories used in the assessment of solutions at the International Exhibition of Inventions of Geneva. We can be 
convinced that the selection of categories, including the assignment of different types of solutions to them, is the result of several decades of experience that also takes into account the changes resulting from the development of science and technology. One can notice the absence or insignificant participation in the exhibition of representatives of economic powers such as the USA, Japan and Western European countries, which may partially disturb the credibility of the conclusions drawn. However, given the current widespread globalization, also in the area of research and development, one can assume that countries with lesser potential are trying to deal with the same topics as the current economic powers [17]. Thus, the new solutions presented at the International Exhibition of Inventions of Geneva can be regarded as a source of knowledge with a high degree of credibility in determining the leading trends in development of innovations.

\section{The Polish National Student-Inventor Competition - Case Study}

The qualification with the use of a map of inventions was also carried out for a set of data obtained and made available as part of the Polish National Student-Inventor Competition. The assessment scale used by experts of the International Exhibition of Inventions of Geneva was applied (Table 1). In this case, it is a single-parameter assessment covering 21 categories, without distinguishing between exhibitors. 90 solutions submitted to the 7th edition of the Competition, which took place in 2017, and 139 solutions submitted to the 9th edition of the Competition, the final of which took place in 2019, were analyzed. A ranking of categories depending on the number of solutions assigned to them is presented in Tables 7 and 8, while in graphic form in Fig.8 and Fig.9. Subsequent rows of the table show percentage shares and cumulative percentage shares. As before, $80 \%$ of inventions belonging to the most numerous categories were included in the analyzed group.

Table 7. Student-Inventor 2017

\begin{tabular}{|c|c|c|c|}
\hline Categories & $\mathrm{M}$ & $\mathrm{A}$ & $\mathrm{C}$ \\
\hline Number of solutions & 28 & 26 & 18 \\
\hline Percentage share & $\stackrel{\circ}{\circ}$ & $\begin{array}{l}\delta_{0}^{\circ} \\
\text { oे }\end{array}$ & $\begin{array}{l}0 \\
8 \\
0\end{array}$ \\
\hline
\end{tabular}

\begin{tabular}{|c|c|c|c|}
\hline Cumulated share & $\stackrel{\partial^{\circ}}{\stackrel{m}{m}}$ & 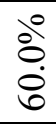 & $\begin{array}{l}\stackrel{0}{0} \\
\stackrel{0}{\infty}\end{array}$ \\
\hline Ranking & 1 & 2 & 3 \\
\hline
\end{tabular}

Source: Own elaboration

Table 8. Student-Inventor 2019

\begin{tabular}{|c|c|c|c|c|c|}
\hline Categories & $\mathrm{M}$ & $\mathrm{A}$ & $\mathrm{K}$ & $\mathrm{D}$ & $\mathrm{C}$ \\
\hline Number of solutions & 59 & 21 & 15 & 11 & 8 \\
\hline Percentage share & $\underset{\stackrel{Ð}{+}}{\stackrel{\circ}{+}}$ & $\frac{\partial}{n}$ & $\begin{array}{l}\stackrel{0}{0} \\
\dot{0} \\
0\end{array}$ & $\frac{\stackrel{0}{\circ}}{n}$ & $\begin{array}{l}\stackrel{0}{\circ} \\
\infty \\
\dot{n}\end{array}$ \\
\hline Cumulated share & $\begin{array}{l}\stackrel{\circ}{+} \\
\stackrel{+}{y}\end{array}$ & $\begin{array}{l}\text { bे } \\
\text { in } \\
\text { in }\end{array}$ & $\begin{array}{l}\dot{0}^{\circ} \\
\text { in }\end{array}$ & ஸें & $\begin{array}{l}\text { oे } \\
\text { oे } \\
\text { do }\end{array}$ \\
\hline Ranking & 1 & 2 & 3 & 4 & 5 \\
\hline
\end{tabular}

Source: Own elaboration

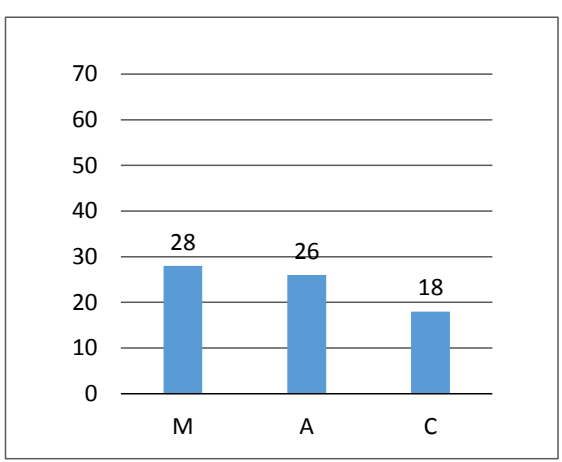

Fig.8: Student-Inventor 2017 - number of solutions in each category

Source: Own elaboration

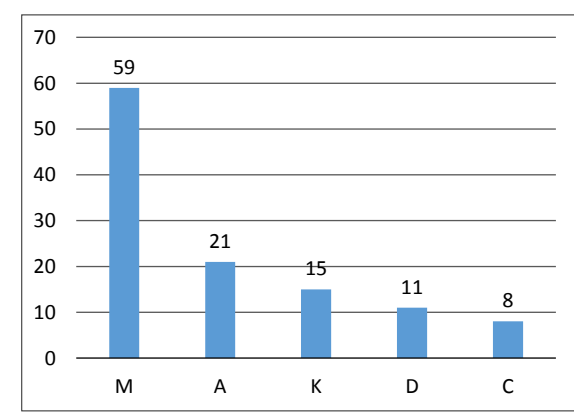

Fig.9: Student-Inventor 2019 - number of solutions in each category

Source: Own elaboration

In the case of the 2017 competition, these were 72 solutions, which account for $82 \%$ of the total number of solutions submitted to the competition. They include only three categories; M, A and C. In the case of the 2019 competition, these were 114 solutions, which is exactly $80 \%$ of the total number of solutions submitted to the competition. They include five categories, the same as in the 2017 competition; $\mathrm{M}, \mathrm{A}, \mathrm{C}$, and additionally categories $\mathrm{K}$, 
D. No solutions corresponding to other categories were submitted for the competition in both editions or their numbers were small and were included in the set of rejected ones (20\%). The most represented categories in the Student-Inventor competition (M, A, C, K, D) indicated in the tables belong to the group defined as the leading areas of innovative development (Table 6). There is a high correlation with the results from the Geneva exhibition, so it is possible to express an opinion about the similarity of the two datasets.

The classification categories at the exhibition in Geneva referred to the recipients of the presented solutions. They indicated the area in which practical solutions can be applied in the form of products after the commercialization process. A different proposal for the rules of classification is a criterion that takes into account the link between the invention and the method of production to a greater extent, which is determined by areas of technology. An exemplary proposal inspired by solutions from the Student-Inventor Competition is a set of ten technological areas presented below.

\section{$\mathrm{X} 1$ - Chemicals}

$\mathrm{X} 2$ - Chemical technologies

X3 - Building materials (excluding new chemicals)

$\mathrm{X} 4$ - Mechanics: production equipment and machines

X5 - Mechanics: utility products

X6 - Electrical Engineering

$\mathrm{X} 7$ - Electronics, IT

X8 - Health (mechanics, electronics, IT)

X9 - Agriculture (mechanics, electrical engineering)

$\mathrm{X} 10$ - Other (practical items)

Such a set of areas of technology results from the analysis of solutions submitted for subsequent editions of the Polish National Student-Inventor Competition and can be extended as needed. One can get the impression that some important areas are missing here, for example: environmental protection, medicine and pharmacology. In this classification approach, it is assumed that environmental protection utilizes products from the areas of mechanics, chemical technology and electricity. Modern building materials also use recycled components to support environmental protection. Similarly, pharmacology is based on products related to chemistry, and medicine widely uses the equipment operating thanks to the achievements of electronics and computer science, and mechanics provides implants, for example hip joint endoprosthesis.
Tables 9 and 10 show the results of assigning the solutions submitted to the Student-Inventor Competition in 2017 and 2019 to the areas of technology proposed in the classification. In both cases, the five initial positions constitute a group covering approximately $80 \%$ of the solutions. The common part in these groups are the following areas of technology: X1, X2, X4, X8.

Table 9. Student-Inventor 2017 - areas of technology

\begin{tabular}{|c|c|c|c|c|c|c|c|c|c|c|}
\hline Categories & X4 & $\mathrm{X} 8$ & $\mathrm{X} 2$ & $\mathrm{X} 1$ & X7 & $\mathrm{X} 5$ & X3 & X6 & X9 & $\mathrm{X} 10$ \\
\hline $\begin{array}{l}\text { Number of } \\
\text { solutions }\end{array}$ & 22 & 18 & 17 & 10 & 9 & 8 & 3 & 2 & 1 & 0 \\
\hline $\begin{array}{l}\text { Percentage } \\
\text { share }\end{array}$ & $\begin{array}{l}\stackrel{0}{+} \\
\dot{d} \\
\end{array}$ & $\begin{array}{l}\stackrel{0}{0} \\
\dot{0} \\
\text { ¿े }\end{array}$ & $\begin{array}{l}\circ \\
\stackrel{\circ}{0} \\
\infty\end{array}$ & $\stackrel{\circ}{\Xi}$ & $\begin{array}{l}\circ \\
\stackrel{0}{0} \\
0\end{array}$ & $\begin{array}{l}a^{\circ} \\
\infty\end{array}$ & iें & तें & $\stackrel{\circ}{ت}$ & 追 \\
\hline $\begin{array}{l}\text { Cumulated } \\
\text { share }\end{array}$ & $\begin{array}{l}\stackrel{\circ}{+} \\
\stackrel{\sim}{ \pm}\end{array}$ & $\begin{array}{l}\stackrel{0}{\dot{8}} \\
\dot{+} \\
\dot{g}\end{array}$ & $\begin{array}{l}\stackrel{0}{0} \\
\tilde{n} \\
\end{array}$ & $\begin{array}{l}\stackrel{0}{+} \\
\dot{I} \\
\end{array}$ & $\begin{array}{l}\stackrel{\circ}{+} \\
\dot{\infty} \\
\end{array}$ & $\begin{array}{l}\stackrel{0}{\tilde{n}} \\
\tilde{n}\end{array}$ & $\frac{\gtrless^{\circ}}{\sigma_{0}^{\circ}}$ & $\begin{array}{l}\stackrel{0}{a} \\
\infty \\
\infty\end{array}$ & $\begin{array}{l}\dot{0} \\
\dot{0} \\
\dot{0}\end{array}$ & $\begin{array}{l}\stackrel{\circ}{0} \\
\dot{8}\end{array}$ \\
\hline Ranking & 1 & 2 & 3 & 4 & 5 & 6 & 7 & 8 & 9 & 10 \\
\hline
\end{tabular}

Source: Own elaboration

Table 10. Student-Inventor 2019 - areas of technology

\begin{tabular}{|c|c|c|c|c|c|c|c|c|c|c|}
\hline Categories & $\mathrm{X} 2$ & X1 & X8 & X9 & X4 & $\mathrm{X} 5$ & X6 & X7 & X10 & $\mathrm{X} 3$ \\
\hline $\begin{array}{l}\text { Number of } \\
\text { solutions }\end{array}$ & 48 & 18 & 15 & 15 & 14 & 14 & 4 & 4 & 4 & 3 \\
\hline $\begin{array}{l}\text { Percentage } \\
\text { share }\end{array}$ & $\begin{array}{l}\stackrel{0}{i} \\
\text { षें }\end{array}$ & ๙ั่ & $\begin{array}{l}{ }_{0}^{\circ} \\
\dot{0} \\
\end{array}$ & $\begin{array}{l}\stackrel{0}{\infty} \\
\dot{0} \\
\end{array}$ & $\stackrel{\circ}{0}$ & $\stackrel{\circ}{\circ}$ & ڤัे & aें & aे & ڤ̀ं \\
\hline $\begin{array}{l}\text { Cumulated } \\
\text { share }\end{array}$ & $\begin{array}{l}\stackrel{0}{i n} \\
\dot{m}\end{array}$ & 究 & $\begin{array}{l}0^{0} \\
i \\
\infty \\
\infty\end{array}$ & $\frac{\partial}{9}$ & $\frac{2}{2}$ & $\begin{array}{l}\stackrel{0}{2} \\
\infty\end{array}$ & $\frac{\partial}{a}$ & $\begin{array}{l}\stackrel{0}{0} \\
\dot{a} \\
a\end{array}$ & $\begin{array}{l}\stackrel{0}{0} \\
\vdots \\
\hat{a}\end{array}$ & $\begin{array}{l}80 \\
8 \\
8\end{array}$ \\
\hline Ranking & 1 & 2 & 3 & 4 & 5 & 6 & 7 & 8 & 9 & 10 \\
\hline
\end{tabular}

Source: Own elaboration

The results in graphic form are presented in Figures 10 and 11. Comparison of the results from these two years is difficult due to the significant difference in the number of submitted inventions (90 inventions in 2017, 139 inventions in 2019). 


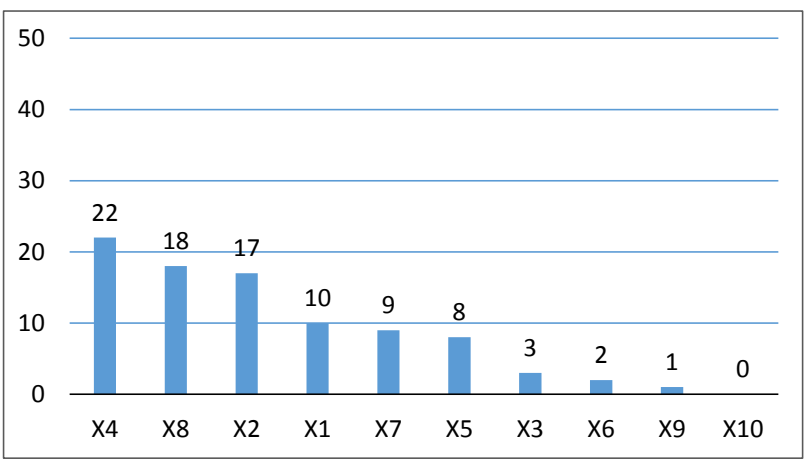

Fig.10: Student-Inventor 2017 - areas of technology (number of solutions)

Source: Own elaboration

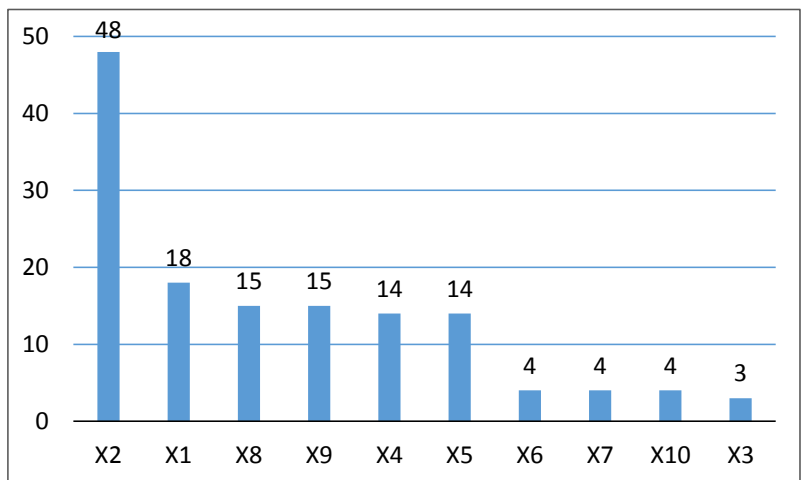

Fig.11: Student-Inventor 2019 - areas of technology (number of solutions)

Source: Own elaboration

When comparing the classification results according to both criteria (Fig. 8 - 11), it can be assumed that most of the solutions from the dominant areas of technology $-\mathrm{X} 1, \mathrm{X} 2, \mathrm{X} 4, \mathrm{X} 8$ belong to categories $\mathrm{M}$ and $\mathrm{A}$ included in the set of leading areas of innovative development (Table 6).

The domination of the areas of technology, considered collectively, i.e. chemical compounds and chemical technologies, seem to be largely in line with reality. [13] Plastics can serve as an example here, as they have had a spectacular effect of the development of chemical technologies over the last few decades. Plastic packaging has become an everyday reality, which, however, we are currently trying to change in observance of environmental protection $[2,10,11,12]$. Water, gas and sewage installations on a micro (apartment) and macro scale (infrastructure) are currently made of plastic pipes. Paints requiring toxic solvents were displaced by water-based acrylic paints. Another example are adhesives with such refined properties that they can replace other traditional types of bonds. A further example are substances used in medicine, many of which were presented in the Student-Inventor Competition, and their distant objective is to create conditions for increasing the comfort of life and its average length.

Here, attention should be paid to the increasing interdisciplinarity and blurring of boundaries between individual areas. Traditional chemistry intertwines with biology which creates a new research area called biochemistry. Traditional mechanics is combined with electronics and computer science creating a research area called mechatronics. This intertwinement of research areas makes it difficult to assign inventions to areas in an unambiguous way and these assessments are often highly subjective.

\section{Conclusions}

The classification of new innovative solutions according to the proposed areas of technology and the analysis of a sample data set allow to indicate the leading trends in research. These are research in areas related to chemistry, concerning the creation of new compounds and the development of new technologies. Conclusions on the leading trends in research are drawn on the basis of limited data sets the Polish National Student-Inventor Competition, which makes generalizations difficult. Due to the lack of detailed data, the classification according to the proposed areas of technology cannot be applied directly to the solutions presented at the exhibition in Geneva. However, the similarity in the structure of applications in the classification according to categories indirectly justifies the assumption of similarity also in the classification according to the areas of technology. Moreover, the observation of changes in the surrounding reality significantly reinforces the conviction that the view on the intensive development of research areas related to chemistry is correct. [5] Such a view slightly interferes with the concept of the fourth industrial revolution associated with the development of computer science. The reason for the low number of IT-related submissions is European patent law, which does not protect algorithms and computer programs - they are not treated as inventions. However, in many cases innovative algorithms appear as components of inventions in the field of mechatronics. However, it is possible to link these two developmental trends by giving the example of the Nobel Prize in Chemistry awarded in 2013 to the creators of computer modeling of complex chemical systems, which allows to transfer experiments from the laboratory to the virtual, digital world. 
References:

[1] Gierulski W., Santarek K., Wiśniewska J., Komercjalizacja i transfer technologii, Polish Economic Publishers, Warsaw 2020, pp. 9-28

[2] Gierulski W., Kaczmarska B., RybaczewskaBłażejowska M., Aspekty ekologiczne winżynierii produkcji - opakowania, in: Inżynieria Zarządzania. Cyfryzacja Produkcji. Aktualności Badawcze 2, Polish Economic Publishers, Warsaw 2020, ISBN: 978-83-2082400-1, pp. 845-857

[3] Gierulski W., Kaczmarska B., Nowakowska M., Promocja wynalazków $w$ procesie komercjalizacji, in: Knosala R. (ed.) Innowacje $\mathrm{w}$ zarządzaniu i inżynierii produkcji, Vol.1, PTZP Publishing House, Opole 2018, pp. 44-55

[4] Kaczmarska B. (ed.), Twórczość młodych wynalazców w rozwoju techniki, Publishing House of the Kielce University of Technology, Kielce 2020, pp. 129-136

[5] Kałowski A., Wysocki J., Start-up a uwarunkowania sukcesu. Wymiar teoretyczno-praktyczny, SGH Publishing House, Warsaw 2017, p. 295

[6] Klincewicz K., Manikowski A., Ocena, rankingowanie $i$ selekcja technologii, Publishing House of the Faculty of Management of the University of Warsaw, Warsaw 2013, pp. 23-36

[7] Catalog of the International Exhibition of Inventions Geneva, 2017

[8] Catalog of the International Exhibition of Inventions Geneva, 2019

[9] Janasz K., Kaczmarska B., Wasilczuk J.E., Przedsiębiorczość i finansowanie innowacji, Polish Economic Publishers, Warsaw 2020, pp. $105-108$

[10] Masternak-Janus A., Metody wspierajace rozwój ekoinnowacji technicznych: ocena cyklu życia (LCA) $i$ rozwinięcie funkcji jakości (QFD), in: Knosala R. (ed.) Innowacje w zarządzaniu i inżynierii produkcji, Vol.1, Oficyna Wydawnicza PTZP, Opole 2018, pp. 100-108

[11] Rybaczewska-Błażejowska M., Sulerz A., LCA as a tool for assessing product and process oriented eco-innovations undertaken by enterprises, Management and Production Engineering Review, 2017, 8(3), pp. 60-69

[12] Rybaczewska-Błażejowska M., Economic, environmental and social aspects of waste management-the LCA analysis, Pragmata tes Oikonomias, 2013, 7, pp. 239-250
[13] Trzmielak D.M., Komercjalizacja wiedzy i technologii - determinanty i strategie, Lodz University Press, Łódź 2013, pp. 45-51

[14] https://palexpo.ch/en/agenda/internationalexhibition-inventions-geneva

[15] www.ksw.tu.kielce.pl

[16] Meshref H., Predicting Loan Approval of Bank Direct Marketing Data Using Ensemble Machine Learning Algorithms, International Journal of Circuits, Systems and Signal Processing, Volume 14, 2020, pp. 914-922

[17] Phanrattinon N., Lenbury Y., Misiran M., Phewchean N., Weak form market efficiency: A case study of Asia-Pacific markets, International Journal of Circuits, Systems and Signal Processing, Volume 14, 2020, pp. 807814

\section{Contribution of Individual Authors to the Creation of a Scientific Article (Ghostwriting Policy) \\ Bożena Kaczmarska - Organizer of the Polish} National Student-Inventor Competition, data acquisition and systematization, analysis, literature review, text preparation.

Wacław Gierulski - data systematization and analysis, statistics development, literature review, text preparation.

\section{Creative Commons Attribution License 4.0 (Attribution 4.0 International, CC BY 4.0)}

This article is published under the terms of the Creative Commons Attribution License 4.0

https://creativecommons.org/licenses/by/4.0/deed .en US 